\title{
"WELCOME TO THE HEART OF THE CITY": MAPPINGS OF LONDON IN EARLY CITY COMEDIES
}

\begin{abstract}
This essay looks at the ways in which the evolving early modern urban space of London was re-presented to early modern Londoners. It focuses on aspects of how the sprawling city was culturally and literally mapped out in theatrical and other performances. It discusses in particular Thomas Middleton's A Chaste Maid in Cheapside and Ben Jonson's The Alchemist as plays that commented respectively on the Cheapside as a luxury market and on Blackfriars as an upand-coming quarter boasting a new and successful theatrical venue. The area between the city and Westminster is also discussed, as is the spatial particularity of Windsor described and performed in Shakespeare's The Merry Wives of Windsor and in contemporary chorography.
\end{abstract}

Keywords: London, Early Modern, theatre, stage, Thomas Middleton, Ben Jonson, Cheapside, Blackfriars, mapping, cartography

Słowa kluczowe: Londyn, nowożytność, teatr, scena, Thomas Middleton, Ben Jonson, Cheapside, Blackfriars, mapowanie, kartografia

In the first scene of the first act of Thomas Middleton's city comedy A Chaste Maid in Cheapside, written and first performed in 1613, the play's main rogue character enters the stage for the first time, addressing the Welsh woman who accompanies him: "Now, wench, thou art welcome to the heart / Of the city of London" (Middleton, 2007, 1.1.101-102). A few lines down he admonishes her: "Here you must pass for a pure virgin" (Middleton, 2007, 1.1.111). The man speaking is the rich, corrupt and, to be sure, tellingly named Sir Walter Whorehound. The Welsh woman, passed off for the time being as a gentlewoman, is described in the play's dramatis personae as "Sir Walter's whore" (Middleton, 2007, p. 912). Sir Walter has taken his whore to London in order 
to marry her off advantageously to an unsuspecting son of the merchant middle class. The place Sir Walter defines as "the heart / Of the city of London" is a shop in Cheapside, the luxury trading hub of early modern London. This heart of the city, entertainingly proclaimed and acted out in the play, is a gilded bauble, the glittering but morally rotten core of a tantalising early modern phantasm of material splendour.

What is more, the shop is located in Goldsmiths Row, visually the most impressive part of consumerist Cheapside. It is here that the wife and the daughter of the affluent goldsmith Yellowhammer are on display for male consumption, very much like the commodities in the family shop. ${ }^{1}$ The stage direction preceding the first scene hints at the nexus between the women's sexualisation and commodification: "Enter Maudline and Moll, a shop being discovered". The audience is faced with the wife and the daughter of Master Yellowhammer, a goldsmith. In the goldsmith's shop, the two women are on Cheapside's market. Addressing her daughter Moll in the first line of dialogue spoken on stage, Maudline Yellowhammer commences the line of sexual innuendo initiated and promised in the play's title: "Have you played over all your old lessons o' the virginals?" (1.1.1-2) The daughters of the Cheapside shopkeepers would often learn how to play the virginal, a small keyboard instrument, as a desirable female accomplishment. At the same time, and consistent with an established bawdy analogy, Maudline is engaging in a double entendre. The unmarried Moll is, for all we know, a virgin, which, even more than her musical accomplishments, guarantees her value on the marriage market. Similarly, the play puts high value on the place of birth of marriageable London youngsters, for Mistress Yellowhammer will later insist that her son Tim, although he tries to impress his future wife with Latin, is English through and through, and that he was "born i' the heart of London!" (4.1.142).

It is in the wide street of Cheapside and in its adjacent lanes that the city's streams of commerce and the play's plots of ruthless greed and reckless lust converge. In his Survey of London (1598; $2^{\text {nd }}$ ed. 1603), the city chronicler John Stow described Cheapside as "the most beautiful frame of fair houses and shops that be within the walls of London, or elsewhere in England" (Stow, 1971, vol. 1, p. 345). The name to this central city space derived from the exchange of commodities in it. Cheapside derives its name from the Anglo-Saxon "ceap": as a verb, this meant "[t]o barter, buy and sell; to trade, deal, bargain"; the noun denoted a marketplace $(O E D)$. Since the middle ages, Cheapside had functioned as the chief marketplace of London; "[i]n the $16^{\text {th }}$ century it was constantly attacked by Puritans" (Weinreb et al., 2008, p. 154).

1 Intertextually, the marriage negotiations and complications in the household of a goldsmith link Middleton's comedy to Chapman's, Jonson's and Marston's Eastward Ho! (1605), the first scene of which begins in front of goldsmith Touchstone's shop - and Touchstone's two daughters Mildred and Gertrude will, like Moll Yellowhammer, be married in the course of Eastward Ho!. 
Taking note of the heavily gendered spaces of $A$ Chaste Maid in Cheapside, Alan Brissenden assumes that the ironic title of Middleton's play may well have been almost proverbial in the early seventeenth century: "A chaste maid in Cheapside? Not likely" (cf. Middleton, 2002, p. 2). To the present day, Cheapside is indeed very much in the centre of the city of London. In the early modern age Cheapside was, as in this play, regarded as the heart of the city which would provide the city with its lifeblood, consumer goods and their attendant flow of capital. As a space of change and exchange, Cheapside renegotiated established or imaginary boundaries in a number of ways. It shared its overall transgressiveness with large parts of the social microcosm that was early modern London. Middleton's play, which refers to no less than twenty-one specific London locales, is representative of early modern theatre's participation in the cultural mapping of early modern London (cf. the illustrations in an online edition of the play; Middleton, 1995). Certainly, A Chaste Maid in Cheapside is by no means the only city comedy staging a keen awareness of London's cultural and spatial concerns, but it serves as a striking performative introduction to them.

Between 1550 and 1600 early modern London's population more than doubled, from about only 70,000-80,000 to about 200,000 inhabitants (see Finlay and Sheare, 1986; Harding 1990). The famous map of London produced for Georg Braun's and Frans Hogenberg's Civitates Orbis Terrarum of 1572 already shows a city spilling over its walls. The city provided the national and international luxury goods consumed both by its elites and by the neighbouring court at Westminster. Since London dwarfed all other towns in the British Isles, its political and cultural predominance was incontestable. London grew and was mapped at a time when modern techniques of mapping were coming into existence - for instance, Gerardus Mercator had published his famous world map in 1569, applying a new kind of projection to facilitate the navigation of sea voyages. Being both material and mental maps of the world (or of those parts of the world Europeans thought they knew), early modern maps were changing fast. As Andrew Gordon points out, it is a rewarding critical attempt "to show how the imaging of the city from above was itself marked by the performance of the city going on down below" (Gordon, 2011, p. 69).

Over the last thirty odd years, scholars have sought to compare the sign systems of literature and cartography for the ways in which they worked and contributed to the shaping of early modern cultures. In Rethinking the Power of Maps, Denis Wood argues: "[...] maps leverage words. Effectively, then, a map is an engine, where an engine is a machine that converts energy to work, and a machine is any device that helps get work done. Maps are engines that convert social energy to social work" (Wood, 2010, p. 1). The performative innovations of the London theatre scene from the middle of the sixteenth century partook in the great cultural effort of channelling the social energies 
of the first British metropolis, mapping out a new urban space infused with new people and new ideas in the process of early modernisation.

A Chaste Maid in Cheapside is a prime example of this mapping of early modern London on stage. As one of the best-known specimens of Jacobean city comedy, a genre that enjoyed its brief heyday during the reign of James I, the play follows established conventions while at the same time subverting and transgressing them to produce more profitable entertainment. ${ }^{2}$ In the first two decades of the seventeenth century, the new genre of city comedy tapped into the equally new mass market for entertainment that London afforded, and into the fascination, the wonder and occasionally the repulsion with which Londoners looked at their changing city. ${ }^{3}$ London's unprecedented growth within just a few decades changed the conventions of its own stage representations equally fast. Traditional ways of describing and performing the city became outdated around the turn of the century. In plays from the last third of the sixteenth century, London had figured, conventionally, as a city of temptation and sin in the tradition of late medieval allegories - Robert Wilson's The Three Ladies of London (1584) is one example. In this tradition, London was hardly more than a contemporary materialisation of the corrupt city as a general idea, in keeping with biblical accounts of sinful Babel, Sodom and Gomorrah.

Jacobean playwrights knew and used the traditional idea of the sinful city in their stage-visions of the city of London. For example, in Eastward Ho!, a city comedy written in collaboration by George Chapman, Ben Jonson and John Marston in 1605, a conventionally allegorical and moralising view of the city is evoked to wrap up the play. At the end, which was probably written by Jonson, the idle apprentice Quicksilver finally repents and asks "that I may go home, through the streets [...], as a spectacle, or rather an example, to the children of Cheapside" (Jonson, 2012, 5.5.179-181). ${ }^{4}$ Upon which Touchstone sententiously addresses the audience: "Now, London, look about, / And in this moral see thy glass run out" (Jonson, 2012, 5.5.181-82). The hour-glass, an equally conventional rhetorical prop in this moralizing interjection, hammers home the familiar message that the wages both of the sins shown in the play and of the city's real sins would conventionally be death. But with a view to the cynicism displayed elsewhere in this play, which hinges on its representation of corrupt dealings in London as much

2 On the increasing popularity of London itself as a setting of comedies produced for the London theatre market, see Grantley, 2008.

3 As Christine Moyrer's following essay demonstrates, Caroline city comedies are indebted to their Jacobean predecessors while they adapt to the changing cultural conditions of London in the decades to come.

4 One of the play's songs begins with the first line 'In Cheapside famous for gold and plate' (Jonson, 2012, 5.5.40). 
as on the virtue of its triumphant main characters, this moralizing at the end is at best a half-hearted, perhaps even a half-ironic gesture. In Eastward Ho! and in other plays of the time, early modern London turned out to be far too multi-facetted and interesting to be contained within the anonymous semantic framework of a latter day Babel.

London was teeming with the multitude and the frissons of the early modern urban experience, and London's criminal underbelly was particularly attractive for stage presentations in city comedies (cf. Howard, 2007, chapters 2-3), as for instance Ben Jonson noted in the prologue to The Alchemist, a city comedy that premiered in 1610, three years before $A$ Chaste Maid in Cheapside:

Our scene is London, 'cause we would make known

No country's mirth is better than our own.

No clime breeds better matter, for your whore,

Bawd, squire, imposter, many persons more,

Whose manners, now called humours, feed the stage,

And which have still been subject for the rage

Or spleen of comic writers.

(Jonson, 2012, 11. 5-11)

The possessive pronoun "your" which precedes the list of characters (characters that hover between stock and individual) intimates that the audience in a way 'owns' these characters, that they are figures of everyday life that belong to the people watching them on stage. The whore, bawd, squire and imposter, stage specimens of familiar city dwellers, are much more theatrically stimulating than morally disgusting; their manners constitute the entertainment the play capitalises on. In plays of the late sixteenth and early seventeenth century, and predominantly, as Jonson argues, in comedies which seemed more suited to such a mundane setting, the criticism of London as a world of crime and debauchery was more than counterbalanced by the fascination of its transgressions.

London was so dynamic that it was proving ever more impossible to contain - spatially, socially and legally. It grew too big, not only for its own city walls, which were soon located within the city space instead that they defined its boundaries, but also for the cognitive frameworks of its inhabitants. Around 1600, London blurred, transgressed or eradicated a multitude of borders and delimitations that had been taken for granted only one or two generations earlier. This border-changing early modern London produced a whole list of challenges, of urgent questions that had to be addressed on more than one level of the communal and administrative debates: How to deal with all these new limits and liminalities? How to enable crossings of newly established in- 
ternal and external borders without destroying them? How to integrate the city, both as 'the centre' and as an anomaly, into the budding concept of the English nation, a nation that was being invented simultaneously to the modern city? How to control the city's immediate margins with their unclear legal status, the new communities in a pluralizing city society and the exploding poverty and criminality? How to manage the shifts of power that came with new spaces and their meanings? How to address the new importance of the numerous in-between spaces? How to come to terms with the influx of immigrants from continental Europe? How to imagine London's growing importance as a centre of global trade?

Being products of the city as a burgeoning marketplace, the new theatres took part in the cultural debates around these questions, some of which had to be identified and formulated in the first place. At the same time, the theatres were spatially and culturally located within the very cityscape they helped to shape. They both profited from and were limited by the fast-changing urban space that brought them forth and sought to marginalise them at the same time. The drama of the day made London recognisable and comprehensible for those who lived in it.

In plays of the early 1600 s, references to London become ever more detailed as the city space is described and inscribed for outsiders and even more for inhabitants. Increasingly, London's transforming districts and neighbourhoods come into focus; in using a thick description of the urban space, the playwrights could rely on Londoners' familiarity with their city. In Ben Jonson's The Alchemist, the trickster prostitute Dol Common berates one of her companions in crime:

Dol Common A whoreson upstart apocryphal captain,

Whom not a puritan in Blackfriars will trust

So much as for a feather!

(Jonson, 2012, 1.1.128-29)

The specificity of the reference alludes to the setting of the play: The house the tricksters use as their base is located in Blackfriars (Jonson, 2012, 1.1.17; 4.1.131), a fashionable and affluent area just inside the city wall in the south-western corner of the city. Sarah Dustagheer notes:

The Alchemist never leaves Blackfriars: the action takes place predominantly inside the house with only a handful of scenes set outside on the doorstep. As well as the claustrophobic intensity of this one Blackfriars house, the name of the area is regularly invoked ensuring the specific location is never far from the audience's consciousness. [...] The antics of [the tricksters] are both particularly out of place and too close to home, because the Blackfriars 
precinct had a reputation for being a wealthy, socially elite area. [...] In 1596, its residents had petitioned against the Chamberlain's / King's Men performing in their newly constructed indoor theatre. (Dustagheer, 2011, p. 101)

Highlighted as "Black-friers" in the London map of John Norden's Speculum Britanniae (vol. 1, 1593), ${ }^{5}$ Blackfriars was an old city space in the process of reinvention. Before the dissolution of the monasteries, Blackfriars had been ecclesiastical territory; the priory of the Dominican (black) friars had been dissolved by Henry VIII in 1538, yet the name remained. In the late sixteenth and early seventeenth centuries, Blackfriars became a coveted and therefore quickly gentrified living area. One of Blackfriars' population groups were Puritans. In The Alchemist, two on-stage Anabaptist zealots, aptly named Tribulation Wholesome and Ananias, enter the stage, and they had real-life counterparts in Blackfriars. As Dol Common points out, Blackfriars was a space of consumption inhabited among others by people who attacked consumption, like all worldly desires, as sinful - and who were selling and buying luxury goods in Blackfriars, for instance costly decorative feathers.

Ben Jonson had lived in Blackfriars from 1603, "living (it is thought) in the great house formerly belonging to Lord Cobham near Playhouse Yard next to the Blackfriars theatre" (Donaldson, 2011, p. 184). The second Blackfriars theatre, ${ }^{6}$ the indoor theatre built from 1596, would become a prime theatrical venue, particularly from 1609, when Shakespeare's company, the King's Men, started playing there for the winter season. The shareholders of the Globe Theatre (which was just opposite on the other bank of the Thames) took equal shares in the Blackfriars theatre, a profitable arrangement that would be interrupted by the burning down of the Globe in 1613 (see Gurr, 2006, pp. 27-28). Crucially, due to the Blackfriars theatre's uncertain legal status as a former possession of the Catholic Church, the city's jurisdiction did not apply to the theatre. The Blackfriars theatre would have been considered a daring stage: "It seems very likely that the Blackfriars plays written between 1601 and 1607 were the most radical ever staged in London between 1574 and 1642." (Gurr, 2009, p. 71) When a comedy about Blackfriars was acted in the Blackfriars theatre, the boundary between the theatrical illusion and the London outside the theatre would become blurred, and the theatre audience would become part of a particularly tense act of cognitive mapping.

\footnotetext{
A reproduction of the 1653 reprint is available online on the website of the British Library at http:// www.bl.uk/onlinegallery/onlineex/crace/a/007000000000001u00033000.html. Interestingly, the name "Black-friers" is written into the uncrowded area of the Thames, which delimits it in the south

6 There had been a first Blackfriars theatre in the hall of the former Blackfriars Dominican priory, which was used after alterations by Richard Farrant from 1576 to 1584 by the Children of the Chapel Royal (see Gurr, 2006).
} 
The Blackfriars theatre figures as the focal point of an anecdote in A Chaste Maid in Cheapside, told by Touchwood Senior:

You heard how one [gentleman] 'scaped out of the Blackfriars,

But a while since, from two or three varlets

Came into the house with all their rapiers drawn,

As if they'd dance the sword-dance on the stage,

With candles in their hands, like chandlers' ghosts,

Whilst the poor gentleman so pursued and bandied

Was by an honest pair of oars safely landed.

(Middleton, 2007, 4.3.6-12)

Neither this anecdote nor the situation it describes have so far been found in any other source. The description of the Blackfriars as a dangerous place (and a dark one - it had to be constantly lit by candles) and the praise of the watermen ("oars") who rescued a gentleman from danger is a piece of advertising on behalf of the watermen and of a theatre, not the Blackfriars but the Swan. The implications of the anecdote become clearer with a view to the title page of the first quarto of $A$ Chaste Maid in Cheapside (1630), where the comedy is described: "As it hath beene often acted at the Swan on the Banke-fide, by the Lady ElizABEth her Seruants". From 1608, the Blackfriars theatre had been a serious competitor of the Bankside theatres (the Rose, the Swan and even the Globe, which was in the summer used by the King's Men, who used the Blackfriars in winter $\left.{ }^{\top}\right)$. The very presence of the Blackfriars harmed the business of the watermen since city audiences no longer had to cross the Thames for the Bankside theatres in order to see a play. Middleton inserted this anecdote as a contribution to the competition between the theatres, as editor Linda Woodbridge accentuates: "to report [the anecdote] on the stage of the Swan was to denigrate a rival theatre, on the wrong side of the river in the watermen's view, as a rowdy, dangerous place." (Middleton, 2007, p. 946) This anecdote, as well as the following short exchange with two courteous watermen, does not contribute anything to the plot of the comedy; it is a narrative insertion in the dramatic action mapping a part of London's theatre scene, and thus a small area of London itself.

In 2012, London theatre archaeologist Julian Bowsher stated: "In the absence of any definitive evidence for the layout of the [Blackfriars] theatre, that reconstructed at

\footnotetext{
7 A space for indoor performances was particularly needed because of the harsh weather conditions in winter, as Andrew Gurr reminds us: "[...] use of either the open-air playhouses or the innyards was a much happier experience in summer than in London's heavy winters, during the mini ice age of the time, which often made the Thames freeze." (Gurr, 2006, p. 19).
} 
Staunton, Virginia, by the American Shakespeare Center is the most plausible" (Bowsher, 2012, p. 120). The American Shakespeare Centre's Blackfriars Playhouse in Staunton, which opened in 2001, derives its dimensions from the research of Irwin Smith (see Smith, 1964). Equally recalling both the design and the proportions of the Blackfriars theatre, the Sam Wanamaker Playhouse on London's Bankside, a part of Shakespeare's Globe opened in 2014, has since become the best-known contemporary recreation of an early modern indoor theatre. In the absence of early modern images of the Blackfriars theatre, other spaces have been sought in order to construct ideas what the Blackfriars may have looked like. The roof construction of the imaginary Blackfriars in Irwin Smith's 1964 study is a copy of the famous double-hammerbeam roof of Middle Temple Hall. Smith had good reason to let himself be inspired by this hall as a partial model of his imaginary Blackfriars. This indoor space was famously used for theatrical productions; for instance, the first documented performance of Shakespeare's Twelfth Night took place there in 1602. The Middle Temple's lavishly carved roof was probably far more costly than the roof of the Blackfriars theatre. In the historicising imagination, the limits of plausibility may perhaps tend to be stretched when Shakespeare is involved.

In terms of their locations within the area of London, the Inns of Court, elitist educational institutions and performance venues, were caught up in the developing cityscape. Until about the mid-sixteenth century, not only the Middle Temple, but all Inns of Court were spaces well outside the city walls, away from the bustle of the city. The atmosphere at the Inns of Court was described around 1470 by Sir John Fortescue as follows:

the situation of the place where [the students of the law] reside and study, is between Westminster and the city of London, which, as to all necessaries and conveniences of life is the best supplied of any city or town in the kingdom: the place of study is not in the heart of the city itself, where the great confluence and multitude of the inhabitants might disturb them in their studies; but in a private place, separate and distinct by itself, in the suburbs, near to the Courts of Justice aforesaid, that the students, at their leisure, may daily and duly attend, with the greatest ease and convenience. (Fortescue, 1917, p. 81)

As Andreas Mahler has noted, around 1600 the Inns of Court were no longer outside the city, they were actually in the middle of an enlarging urban space, between the encroaching city and Westminster (see Mahler, 2011, p. 24-26), a space that, given the Western expansion of city life, would become ever more prominent in the $1620 \mathrm{~s}$ and 1630s. The Inns of Court were four locations and social formations that, typical of early modern London and its fluent borders, found themselves in a state of in-between- 
ness, looking towards the city in the east and the court in the west. The Inns of Court had their very own tradition of theatrical performances among their entertainments, and they acknowledged the professionalization of the theatre: "After 1587-8 far more plays were furnished to the Inns of Court by outside professionals than by inside amateurs." (Nelson and Winston 2010, n.p.) The two playwrights most closely connected to the Inns of Court were John Marston and Francis Beaumont. The in-between spaces of the Inns of Court commented on the two centres of power adjacent to them, the city and the court, and they were all situated in proximity to the Blackfriars district and its theatre scene. Both the Inns of Court and the Blackfriars district are examples of early modern London urban spaces which were defined by traditional boundaries, redefined in the rapid process of modernisation and culturally mapped, also through theatrical performances. Both of these highly cultured spaces questioned old oppositions: they were in different ways neither in nor out, neither completely here nor completely there, wherever plays set in them were performed.

London was an ensemble of spaces that in many respects resisted fixed limits and boundaries. Its influence extended into the towns and hamlets in its surroundings and in the settings of his plays, Shakespeare never got closer to London than its hinterlands. It is well-known that Shakespeare never wrote a proper London city comedy and that he never represented the city he knew on stage, much to the regret of many scholars of early modern theatre. In a few cases, though, the cities Shakespeare chose and mapped as pseudo-exotic locations are, at least in some respects, recognisable as camouflaged versions of London. One famous example is the Vienna of Measure for Measure with its centres of power, its city gate, with Mariana in the moated grange, its streets of petty crime and its prison full of eccentrics. It is only in one play that Shakespeare came at least close to actually putting London on stage - he wrote about what we might call one of its suburbs. This almost-city comedy of Shakespeare first appeared in a quarto in 1602 under the title $A$ Most pleafaunt and excellent conceited Comedie, of Syr Iohn Falstaffe, and the merrie Wines of Windsor.

The Merry Wives of Windsor stages, warts and all, the bourgeois community of a small town not too far from London. The prime source of comedy in this play are certainly Sir John Falstaff's failed attempts at seducing the eponymous merry wives of two of Windsor's middle-class townsmen and Falstaff's entertaining humiliations resulting from his abortive wooing attempts. The indestructible Falstaff is first and foremost interested in the wealth of the husbands; the physical dimension of enjoying the wives' favours clearly takes second place for him. He makes this quite clear, for instance when he thinks about Mistress Page and metamorphoses her into something quite different: "She is a region in Guiana, all gold and bounty. I will be cheaters to them both, and they shall be exchequers to me. They shall be my East and West Indies, and 
I will trade to them both." (Shakespeare, 2016, 1.3.58-61) Falstaff rhetorically manifests his transgressive material desires. Within the mental framework of the time-honoured analogy between women and land, he turns the wives into fabled and exotic countries which have just come within the European colonialist reach. Falstaff's fabulations were presented at a time when London's colonial ambitions were being manifested in the founding of joint stock companies such as the East India Company (1600) and the Charter of the Virginia Company of London (1606).

Like the knights and lords who have failed to win Mistress Ford, Falstaff is a representative of the Windsor court nearby. He is an aristocratic intruder in this clear-cut middle-class world of comfortable wealth and marital fidelity. The fat Falstaff embodies the pretensions of the neighbouring court, and the comedy flaunts the bourgeois self-confidence of Windsor's townfolk against these courtly pretensions. Master Page claims that his complete trust in his wife's fidelity is more important for him than anything anybody could offer, and he attacks the jealous Master Ford: "I would not ha' your distemper in this kind for the wealth of Windsor Castle." (3.3.182-183) Symbolising the riches of the realm, Windsor Castle is here contrasted with the self-confidence of the people living under its walls. The Merry Wives of Windsor stages the proximity between the town and the court. This proximity was an everyday reality for the people of Windsor, which is also evident in contemporary maps, for instance in the Windsor map in John Norden's A Description of the Honour of Windesor (1607). The royal castle is a presence in the background of Shakespeare's middle-class comedy, just like Whitehall and Westminster were constant presences for the citizens downstream.

Cultural mappings of London and its environs, overt and covert, were a conventional element of early modern theatre, and the processes and minutiae of these stage mappings as well as their interactions with the actual urban space they re-presented have become a field of research in their own right. Both early modern London and its theatre scene would undergo drastic changes within the time span of only a few decades, though, changes which would alter both beyond recognition in the eyes of Elizabethans and Jacobeans. Perhaps these changes were anticipated in one of our core texts, Ben Jonson's The Alchemist, at its very beginning. In "The Argument", which precedes the prologue quoted above and which offers a reduced synopsis of the play, the author's persona predicts the end of the play when the Blackfriar tricksters have been discovered:

Much company they [the tricksters] draw and much abuse

In casting figures, telling fortunes, news,

Selling of flies, flat bawdry, with the stone,

Till it and they and all in fume are gone. 
(Jonson, 2012, 9-12)

For all the busy stage business that is to come, the end is predestined to come in the form of an all-encompassing dissolution. The tricksters will go up in the fumes of pseudo-alchemy they have created to keep their business going: "Till it and they and all in fume are gone." It is clear from the beginning that a final conflagration, a spontaneous combustion will put an end to the untrustworthy performances of this Blackfriars comedy. The district of Blackfriars, at least on stage, will be consumed with that which it is nourished by.

With the benefit of hindsight, we may also be inclined to see another kind of (long-term and unwitting) foreshadowing in the preceding quotation. This foreshadowing would relate to the arguably real London which The Alchemist, in an act of stage magic, presupposes and constructs. The civil war and the Puritan rule would put an end to London's theatre scene; the Blackfriars theatre was demolished in 1655. More importantly, early modern London itself, that fast-growing metropolis Middleton, Jonson and Shakespeare knew and that they prospered on, would be changed dramatically. First, the cultural life of London would undergo fundamental changes during the civil wars and the time of puritan rule, changes that would destroy the theatrical mapping that had established itself since the late sixteenth century. And after this cultural change, early modern London itself, with its cloud-capped towers, its gorgeous palaces, its solemn temples, yea, all which it inherit, would soon dissolve and leave not a rack behind. From the second to the fifth of September 1666, the Great Fire would rage through the old city. On the $6^{\text {th }}$ of September, 1666, the old London all in fume was gone. It turned into an ever more blurred cultural memory, a phantom to be conjured up and traced, in old maps and in the cultural mappings of early modern plays.

But this future of their proud city was inconceivably far off for the Londoners who went to the theatres inside and outside the city walls. In the 1610s - the decade that produced both The Alchemist and A Chaste Maid in Cheapside - few would probably have judged that early modern London's glass was running out. Amassing ever more people and capital, the city kept outgrowing its medieval limits at an unabated pace, and the theatre scene, the city's most successful new entertainment industry, was equally thriving. Before early modern London met its material end in 1666, and before the theatres were closed in 1642, city comedies of the 1620s and 1630s kept re-presenting the continuing expansion of the city in stage performances that distorted London's everyday life in order to render it more entertaining and comprehensible to those who lived it. While the novelty of seeing London on London stages gradually wore off, new topics and new characters entered the stages, catering to the specific interests and demands of post-Jacobean London. As Christine Moyrer's following essay demonstrates, playw- 
rights like Richard Brome entertained their audiences by having revised city characters interact in new city spaces, outside the Western wall, in order to discuss new problems that concerned Londoners in the ever more brittle cultural climate of the Caroline age.

\section{Bibliography}

Bowsher, J. (2012). Shakespeare's London Theatreland: Archaeology, History and Drama. London: Museum of London Archaeology.

Donaldson, I. (2011). Ben Jonson: A Life. Oxford: Oxford University Press.

Dustagheer, S. (2011). 'Our Scene is London': The Alchemist and Urban Underworlds at the Blackfriars Playhouse. Shakespeare Jahrbuch, vol. 147, pp. 94-104.

Finlay, R. \& Shearer, B. (1986). Population Growth and Suburban Expansion. In A.L. Beier \& R. Finlay (eds.), London 1500-1700: The Making of the Metropolis, (pp. 37-59). Harlow: Longman, Harlow.

Fortescue, J. (1917). Sir John Fortescue's Commendation of the Laws of England. Trans. F. Grigor. London: Sweet and Maxwell.

Gordon, A. (2011). Performing London: The Map and the City in Ceremony. In A. Gordon \& B. Klein, B. (eds.), Literature, Mapping and the Politics of Space in Early Modern Britain (pp. 69-88). Cambridge: Cambridge University Press.

Grantley, D. (2008). London in Early Modern English Drama: Representing the Built Environment, Basingstoke: Palgrave Macmillan.

Gurr, A. (2009). The Shakespearean Stage 1574-1642 (4 ${ }^{\text {th }}$ ed.). Cambridge: Cambridge University Press. https://dx.doi.org/10.1017/CBO9780511819520.

Gurr, A. (2006). London's Blackfriars Playhouse and the Chamberlain's Men. In P. Menzer (ed.) Inside Shakespeare: Essays on the Blackfriars Stage (pp. 17-34). Selinsgrove: Susquehanna University Press.

Harding, V. (1990). The Population of London, 1550-1700: A Review of the Published Evidence. London Journal, vol. 15, pp. 111-128. https://dx.doi.org/10.1179/ldn.1990.15.2.111.

Howard, J. (2007). Theater of a City: The Places of London Comedy, 1598-1642. Philadelphia: University of Pennsylvania Press.

Jonson, B. (2012). Eastward Ho!. Ed. S. Gossett \& K.D. Kay. In D. Bevington, M. Butler \& I. Donaldson (eds.), The Cambridge Edition of the Works of Ben Jonson, vol. 2: 1601-1606 (pp. 534640). Cambridge: Cambridge University Press.

Jonson, B. (2012). The Alchemist. Eds. P. Holland \& W. Sherman. In D. Bevington, M. Butler \& I. Donaldson (eds.), The Cambridge Edition of the Works of Ben Jonson, vol. 3: 1606-1611 (pp. 555-710). Cambridge: Cambridge University Press.

Mahler, A. (2011). Urbane Raumpraxis und kulturelle Explosion - Netzwerkkonstellationen im frühneuzeitlichen London. Shakespeare Jabrbuch, vol. 147, pp. 11-33.

Middleton, T. (2007). A Chaste Maid in Cheapside. Ed. L. Woodbridge. In G. Taylor \& J. Lavagnino (eds.), Thomas Middleton: The Complete Works (pp. 907-958). Oxford: Oxford University Press.

Middleton, T. (1995), A Chaste Maid in Cheapside. Retrieved from http://www.tech.org/ cleary/ chast.html [accessed: 22.02.2017]. 
Nelson, A.H. \& Winston J. (2010). Drama of the Inns of Court. In M. Hattaway (ed.), A New Companion to English Renaissance Literature and Culture (pp. 94-104). London: Blackwell Publishing. https://doi.org/10.1002/9781444319019.ch46.

Norden, J. (1607). A Description of the Honour of Windesor, [map]. Retrieved from https://www. bl.uk/collection-items/description-of-the-honor-of-windesor.

Norden, J. (1593-1604). Speculum Britanniae, London.

Shakespeare, W. (1602). A Most Pleafaunt and Excellent Conceited Comedie, of Syr Iohn Falstaffe, and the Merrie Wines of Windsor, London.

Shakespeare, W. (2016). The Merry Wives of Windsor. In S. Greenblatt (ed.), The Norton Shakespeare $\left(3^{\text {rd }}\right.$ ed.) (pp. 1474-1531). New York: Norton.

Smith, I. (1964). Shakespeare's Blackfriars Playhouse: Its History and Its Design. London: Peter Owen. Stow, J. (1971). A Survey of London (1603). Ed. C.L. Kingsford. 2 vols. Oxford: Clarendon Press. Weinreb, B. et al. (2008). The London Encyclopaedia ( $3^{\text {rd }}$ ed.). London: Macmillan.

Wood, D. (2010). Rethinking the Power of Maps. New York: Guilford Publications. 